Check for updates

Cite this: RSC Adv., 2017, 7, 24970

\title{
Spirolactam capped cyanine dyes for designing NIR probes to target multiple metal ions $\uparrow$
}

\author{
Chirantan Kar, ${ }^{a}$ Yutaka Shindo, ${ }^{\mathrm{b}}$ Kotaro Oka, ${ }^{\mathrm{b}}$ Shigeru Nishiyama, ${ }^{\mathrm{c}}$ Koji Suzuki ${ }^{\mathrm{a}}$ \\ and Daniel Citterio (iD *a
}

A cyanine based spirocyclic metal ion probe has been reported, which can be tuned easily for targeting various metal ions. The mechanism of selective sensing was verified by designing two novel compounds IR-NCS and IR-PYR, which can selectively sense $\mathrm{Hg}^{2+}$ and $\mathrm{Zn}^{2+} / \mathrm{Cd}^{2+}$ ions respectively in a mixed aqueous medium and physiological $\mathrm{pH}$. The spectral changes in both the cases are in the near infrared (NIR) region. Both chemodosimetric and coordination based approaches were used for sensing the cations. The complete mechanism of the sensing events was studied using UV-Vis and fluorescence spectroscopy. Additional insight about the experimental findings was corroborated by theoretical studies using DFT calculations. The confocal microscopic study revealed that the probe IR-NCS can be effectively used for detecting intracellular levels of $\mathrm{Hg}^{2+}$ ions without showing any toxic effect to the model human cells.

Received 20th March 2017 Accepted 29th April 2017

DOI: $10.1039 / \mathrm{c} 7 \mathrm{ra03246c}$

rsc.li/rsc-advances cofactors. Due to the major role of metal ions in environmental and biological systems a better understanding of transition metals in their labile form is necessary. Accordingly, significant interest has been observed in developing selective and sensitive signalling units for different important metal ions. ${ }^{3}$

Recently, various groups have reported different chemosensors for selective sensing of metal ions, with spectral response in the visual region. ${ }^{4-14}$ Although optical probes showing visual changes have considerable roles in various research areas, lately chemosensors with absorption and emission at the near-infrared region (NIR, 650-1000 $\mathrm{nm}$ ) are gaining special interest. ${ }^{15}$ The amount of scattering of any electromagnetic radiation is inversely proportional to its wavelength, thus for long wavelength NIR radiation the possibility of scattering is less. Due to minimized scattering NIR radiation provides high sample penetration compared to ultra violet or visible radiation. Moreover, the interference generated due to autofluorescence from the chromophores and macromolecules present in the analytic sample is reduced, which enables the study of molecular and physiological events in several layers deep inside the analyte samples and tissues. ${ }^{16}$ Although there have been a few reports on NIR sensing of cations, but newer strategies of designing versatile NIR chemosensors for targeting various metal ions are still required.

To date, various NIR dyes have been applied as signal reporters of chemosensors, such as 1,8-naphthalimide, ${ }^{17,18}$ xanthenes, ${ }^{19}$ boron dipyrromethene difluoride (BODIPY), ${ }^{20,21}$ etc. Among them cyanine based platforms have attracted substantial interest from researchers around the world because these dyes show favourable spectral properties such as high fluorescence quantum yield, high absorption coefficient with 
narrow absorption band and spectral response (absorbance and fluorescence) in relatively longer wavelength..$^{22}$ Additionally, low toxicity and high degree of biocompatibility to living cells and organisms further make cyanine dyes an attractive platform for biological and medicinal application. Although most of the chemosensors designed on cyanine platforms are based on photoinduced electron transfer (PET) based switch OFF-ON, due to their high lying occupied molecular orbital (HOMO) energy, quenching the fluorescence by the PET process alone is difficult. ${ }^{23}$

General strategies which are employed to generate metal dependent optical response from a chemosensor, are either reversible sensing based on coordination of the sensor molecule with the metal ions or irreversible sensing based on chemical reaction of the chemosensor (chemodosimeter) with specific metal ions. Most of the classical metal ion sensors are based on coordination approach, this kind of chemosensors are generally reversible in nature and can be used for several cycles. In some cases where the sensor-analyte coordination has optimum bond strength, they can even be used for extracting the target metal ions from a mixture..$^{24}$ As one of the emerging sensing strategies, chemodosimetric detection of metal ions has attracted increasing attention because of irreversible chemical change of the dosimeter molecule in presence of target species, causing specific spectral response in the emission or absorption spectra. Thus, these kinds of sensors have additional advantages in terms of accuracy and selectivity of detection compared to those based on complexation or coordination effect. ${ }^{25,26}$ Taking the above needs into consideration various chemosensors for environmentally hazardous and benign metal ions have been reported. Among various hazardous metal ions mercury is one of the most harmful and abundant pollutant, its contamination is extensive and can be generated from various natural and anthropogenic sources..$^{27,28}$ Once mercury makes its way into the food chains, it causes serious damage to the human health and ecology. ${ }^{29-31}$ Furthermore, introduction of a small quantity of mercury can be concentrated to harmful levels due to the natural process of bioaccumulation. Similar to mercury, cadmium is also a notorious contaminant and carcinogenic metal. ${ }^{32}$ Route of intake for cadmium is also widespread, although inhaling cadmium containing dust is the major way of intake but it may also take place through smoking and food. Cadmium is found mostly in electroplated steel, pigments in plastics, electric batteries, etc. $^{33}$ A high exposure to cadmium can damage liver and kidneys, increase the risks of cardiovascular diseases and cancer. Owing to these health hazards, cadmium is listed as number 7 on ATSDR's "CERCLA Priority List of Hazardous Substances" ${ }^{34}$ which can cause acute and chronic toxicity. Apart from hazardous mercury and cadmium, zinc is an essential element involved in various crucial biological processes, like cellular metabolism, neurotransmission, and apoptosis. ${ }^{35}$ Zinc is also known to exist as a structural component of proteins or in the catalytic site of enzymes. ${ }^{36}$ As an essential micronutrient, deficiency of zinc can lead to immune dysfunction, impaired cognition, diarrhea, and death, primarily in children under the age of 5 years. ${ }^{37}$ The human genome is known to encode two dozen $\mathrm{Zn}^{2+}$ specific transporters and many metal-buffering proteins, expressed in a tissue specific manner. ${ }^{38}$ However, unlike other essential transition metal ions $\left(v i z ., \mathrm{Fe}^{2+}, \mathrm{Cu}^{2+}\right.$, $\left.\mathrm{Mn}^{2+}\right), \mathrm{Zn}^{2+}$ ion is spectroscopically and magnetically inert. Therefore, common analytical techniques, like Mossbauer, NMR, and EPR spectroscopy cannot detect a typical zinc ion in complex biological or environmental systems. Considering the environmental importance and physiological implications of $\mathrm{Hg}^{2+}, \mathrm{Cd}^{2+}$, and $\mathrm{Zn}^{2+}$ there is significant interest in developing selective and sensitive sensors for these metal ions.

Herein, we described a new method for designing and synthesizing cyanine based NIR fluorescence probes which can be easily tuned for targeting various metal ions. We have verified the potential of our strategy by the synthesis of two new hydrazine functionalized spirolactam capped cyanine probes where we have demonstrated the chemodosimetric approach to detect $\mathrm{Hg}^{2+}$ ions and coordination based approach for sensing $\mathrm{Zn}^{2+} / \mathrm{Cd}^{2+}$ metal ions. We have also conducted quantum mechanical calculation to rationalize our experimental findings.

\section{Experimental section}

\section{General information and materials}

All of the materials for synthesis were purchased from commercial suppliers and used without further purification. The absorption spectra were recorded on a UV-1800 (Shimadzu co. Kyoto, Japan) spectrophotometer using $10 \mathrm{~mm}$ path length quartz cuvettes in the range of $300-900 \mathrm{~nm}$ wavelengths, and the fluorescence measurements were carried on a SREX Fluorolog-3 (Model FL-3-11, Horiba Jobin Yvon, Kyoto, Japan) spectrofluorometer using $10 \mathrm{~mm}$ path length quartz cuvettes with a slit width of $5 \mathrm{~nm}$ at $298 \mathrm{~K}$. The High-Resolution MS spectra (HR-MS) of IR-NCS, IR-HGP, IR-PYR and the corresponding metal complex were obtained on a Waters LCT Premier XE with $\mathrm{MeOH}$ as the solvent. NMR spectra were recorded on a JEOL ECA $500 \mathrm{MHz}$ instrument. The chemical shifts were recorded in parts per million (ppm) on the scale. The following abbreviations are used to describe spin multiplicities in ${ }^{1} \mathrm{H}$ NMR spectra: $\mathrm{s}=$ singlet; $\mathrm{d}=$ doublet; $\mathrm{t}=$ triplet; $\mathrm{m}=$ multiplet. Tetramethylsilane (TMS) was used as an internal standard for NMR spectroscopy.

\section{Synthesis of I1}

IR-780 (200.0 mg, $0.3 \mathrm{mmol})$, 2-carboxyphenylboric acid (100.0 mg, $0.6 \mathrm{mmol})$, and $\mathrm{K}_{3} \mathrm{PO}_{4} \cdot 7 \mathrm{H}_{2} \mathrm{O}(75.0 \mathrm{mg}, 0.35 \mathrm{mmol})$ dissolved in $6 \mathrm{~mL} \mathrm{DMF} / \mathrm{H}_{2} \mathrm{O}(\mathrm{v} / \mathrm{v}=5: 1)$ were heated at $90{ }^{\circ} \mathrm{C}$ in the presence of $\mathrm{Pd}\left(\mathrm{PPh}_{3}\right)_{4}$ (catalytic amount) for overnight under argon atmosphere. The reaction mixture was cooled to room temperature, and poured in $100 \mathrm{~mL}$ ice water. The mixture was extracted thrice using $\mathrm{CH}_{2} \mathrm{Cl}_{2} / \mathrm{C}_{2} \mathrm{H}_{5} \mathrm{OH}(\mathrm{v} / \mathrm{v}=$ $10: 1$ ). The organic phase was separated, washed with brine, and dried with anhydrous $\mathrm{Na}_{2} \mathrm{SO}_{4}$. The solvent was removed under reduced pressure to give the crude product, which was purified by column chromatography (using Merck Aluminium oxide 90 active basic) using $\mathrm{CH}_{2} \mathrm{Cl}_{2}$ to $\mathrm{CH}_{2} \mathrm{Cl}_{2} / \mathrm{C}_{2} \mathrm{H}_{5} \mathrm{OH}(\mathrm{v} / \mathrm{v}$ $100: 1$ to $95: 5)$ as eluent to afford the compound I1 as 
a green solid (78 mg, 33.3\% yield) ${ }^{1} \mathrm{H}$ NMR [500 $\mathrm{MHz}, \mathrm{CD}_{3} \mathrm{OD}$, $\left.\mathrm{SiMe}_{4}, J(\mathrm{~Hz}), \delta(\mathrm{ppm})\right]:$ 8.10-8.12 $(1 \mathrm{H}, \mathrm{m}), 7.52-7.54(2 \mathrm{H}, \mathrm{m})$, $7.32(1 \mathrm{H}, \mathrm{d}, J=5.0 \mathrm{~Hz}), 7.28(4 \mathrm{H}, \mathrm{t}, J=6.5 \mathrm{~Hz}), 7.13(4 \mathrm{H}$, quartet, $J=16.25 \mathrm{~Hz}), 7.05-7.07(2 \mathrm{H}, \mathrm{m}), 6.08(2 \mathrm{H}, \mathrm{d}, J=13.5 \mathrm{~Hz}), 3.98$ $(4 \mathrm{H}, \mathrm{t}, J=7.0 \mathrm{~Hz}), 2.70-2.75(2 \mathrm{H}, \mathrm{m}), 2.61-2.67(2 \mathrm{H}, \mathrm{m}), 2.15$ (1H, broad s), $1.96(1 \mathrm{H}$, broad s), 1.75-1.82 $(4 \mathrm{H}, \mathrm{m}), 1.22(6 \mathrm{H}, \mathrm{s})$, $1.12(6 \mathrm{H}, \mathrm{s}), 0.99(6 \mathrm{H}, \mathrm{t}, J=7.5 \mathrm{~Hz}) .{ }^{13} \mathrm{C} \mathrm{NMR}\left[125 \mathrm{MHz}, \mathrm{CDCl}_{3}\right.$, $\mathrm{SiMe}_{4}, \delta$ (ppm)]: 173.7, 172.8, 168.5, 149.8, 144.1, 142.3, 141.6, $139.8,132.9,131.6,131.5,130.1,129.6,129.1,125.5,123.4$, 111.5, 100.5, 49.9, 46.2, 28.7, 28.3, 25.9, 22.5, 21.7, 11.8. ESI-MS (positive mode, $\mathrm{m} / \mathrm{z}$ ). Calcd for $\mathrm{C}_{43} \mathrm{H}_{49} \mathrm{~N}_{2} \mathrm{O}_{2}: 625.3794$ (M). Found: $m / z$ 625.3878. Melting point: $146-154{ }^{\circ} \mathrm{C}$.

\section{Synthesis of $\mathbf{I} 2$}

I1 (78.0 mg, $0.1 \mathrm{mmol}), N$-hydroxysuccinimide $(23.5 \mathrm{mg}, 0.2$ $\mathrm{mmol})$, and $N, N^{\prime}$-dicyclohexyl carbodiimide $(58.0 \mathrm{mg}, 0.3 \mathrm{mmol})$ were dissolved in $3 \mathrm{~mL}$ dichloromethane, and the reaction mixture was stirred at room temperature for $1 \mathrm{~h}$. The solvent was removed under reduced pressure to give the intermediate, which was dissolved in $2 \mathrm{~mL} \mathrm{DMF}$ and $0.5 \mathrm{~mL}$ of hydrazine hydrate was added, the solution was stirred at room temperature for another $12 \mathrm{~h}$. The colour of the reaction mixture changed from green to orange. The mixture was poured to 50 $\mathrm{mL}$ cold water and extracted three times using $\mathrm{CH}_{2} \mathrm{Cl}_{2}$. The organic phase was collected, dried using $\mathrm{Na}_{2} \mathrm{SO}_{4}$ and concentrated under reduced pressure to get the crude mixture. The reaction mixture was concentrated under reduced pressure to give the crude product, which was purified by column chromatography (using basic Alumina) using $\mathrm{CH}_{2} \mathrm{Cl}_{2}$ to $\mathrm{CH}_{2} \mathrm{Cl}_{2}$ / $\mathrm{C}_{2} \mathrm{H}_{5} \mathrm{OH}(\mathrm{v} / \mathrm{v} 100: 0$ to $97: 3$ ) as eluent to afford the compound I2 as a dark orange solid, the compound has a tendency to degrade during column chromatography (50 mg, $0.08 \mathrm{mmol}$, $80 \%$ yield). ${ }^{1} \mathrm{H}$ NMR [500 $\left.\mathrm{MHz}, \mathrm{CDCl}_{3}, \mathrm{SiMe}_{4}, J(\mathrm{~Hz}), \delta(\mathrm{ppm})\right]$ : $7.91(1 \mathrm{H}, \mathrm{d}, J=8.0 \mathrm{~Hz}), 7.43-7.50(2 \mathrm{H}, \mathrm{m}), 7.38(1 \mathrm{H}, \mathrm{t}, J=8.0$ $\mathrm{Hz}), 7.08(2 \mathrm{H}, \mathrm{t}, J=7.0 \mathrm{~Hz}), 7.0(2 \mathrm{H}, \mathrm{d}, J=7.0 \mathrm{~Hz}), 6.75(2 \mathrm{H}, \mathrm{t}, J$ $=7.5 \mathrm{~Hz}), 6.5(2 \mathrm{H}, \mathrm{d}, J=7.5 \mathrm{~Hz}), 6.16(2 \mathrm{H}, \mathrm{d}, J=12 \mathrm{~Hz}), 5.27$ $(2 \mathrm{H}, \mathrm{d}, J=12 \mathrm{~Hz}), 3.97(2 \mathrm{H}, \mathrm{s}), 3.47(4 \mathrm{H}, \mathrm{t}, J=7.5 \mathrm{~Hz}), 2.88-2.95$ $(2 \mathrm{H}, \mathrm{m}), 2.58-2.64(2 \mathrm{H}, \mathrm{m}), 2.00-2.06(1 \mathrm{H}, \mathrm{m}), 1.83-1.90(1 \mathrm{H}$, $\mathrm{m}), 1.66(4 \mathrm{H}, \mathrm{dd}, J=14.4, J=7.5 \mathrm{~Hz}), 1.38(6 \mathrm{H}, \mathrm{s}), 1.14(6 \mathrm{H}, \mathrm{s})$, $0.95(6 \mathrm{H}, \mathrm{t}, J=8.0 \mathrm{~Hz}) .{ }^{13} \mathrm{C}$ NMR $\left[125 \mathrm{MHz}, \mathrm{CDCl}_{3}, \mathrm{SiMe}_{4}\right.$, $\delta(\mathrm{ppm})]: 167.3,156.1,152.2,145.3,138.8,131.8,128.6,127.7$, 127.4, 126.2, 123.9, 121.9, 121.7, 120.9, 119.0, 105.8, 91.0, 75.2, 45.2, 44.1, 28.5, 26.1, 23.6, 19.8, 11.9. ESI-MS (positive mode, $\mathrm{m}$ / $z$ ). Calcd for $\mathrm{C}_{43} \mathrm{H}_{51} \mathrm{~N}_{4} \mathrm{O}: 639.4063(\mathrm{M}+\mathrm{H})$. Found: $m / z 639.4087$. Melting point: $72{ }^{\circ} \mathrm{C}$ (decomposed).

\section{Synthesis of IR-NCS}

The hydrazide $\mathbf{I} 2$ (30 $\mathrm{mg}, 0.046 \mathrm{mmol}$ ) and phenyl isothiocyanate $(18.16 \mathrm{mg}, 0.13 \mathrm{mmol})$ were dissolved in $1 \mathrm{~mL}$ of DMF and the resulting solution was stirred for $10 \mathrm{~h}$ in room temperature. The reaction mixture was concentrated under reduced pressure, and the solid was collected. The crude mixture was purified with column chromatography (using basic Alumina) using $\mathrm{CH}_{2} \mathrm{Cl}_{2}$ to $\mathrm{CH}_{2} \mathrm{Cl}_{2} / \mathrm{C}_{2} \mathrm{H}_{5} \mathrm{OH}$ (v/v $100: 0$ to $97: 3$ ) as eluent to afford the compound IR-NCS as greenish solid (11 mg, 30\% yield). ${ }^{1} \mathrm{H}$ NMR [500 MHz, $\mathrm{CDCl}_{3}, \mathrm{SiMe}_{4}, J(\mathrm{~Hz})$, $\delta(\mathrm{ppm})]: 8.39(1 \mathrm{H}, \mathrm{s}), 8.04(1 \mathrm{H}, \mathrm{d}, J=7.5), 7.72(1 \mathrm{H}, \mathrm{t}, J=7.5$ $\mathrm{Hz}), 7.59(1 \mathrm{H}, \mathrm{t}, J=7.5 \mathrm{~Hz}), 7.53(2 \mathrm{H}, \mathrm{d}, J=8 \mathrm{~Hz}), 7.41(2 \mathrm{H}, \mathrm{d}, J=$ $8 \mathrm{~Hz}), 7.18(2 \mathrm{H}, \mathrm{t}, J=7.5 \mathrm{~Hz}), 7.11(2 \mathrm{H}, \mathrm{t}, J=7.5 \mathrm{~Hz}), 7.07(1 \mathrm{H}, \mathrm{t}$, $J=7.5 \mathrm{~Hz}), 6.96(2 \mathrm{H}, \mathrm{d}, J=7.0 \mathrm{~Hz}), 6.78(2 \mathrm{H}, \mathrm{t}, J=7.0 \mathrm{~Hz}), 6.56$ $(2 \mathrm{H}, \mathrm{d}, J=8 \mathrm{~Hz}), 6.35(2 \mathrm{H}, \mathrm{d}, J=11 \mathrm{~Hz}), 5.23(2 \mathrm{H}, \mathrm{d}, J=11 \mathrm{~Hz})$, 3.486 (4H, broad peak), 2.79-2.83 $(2 \mathrm{H}, \mathrm{m}), 2.57-2.61(2 \mathrm{H}, \mathrm{m})$, 2.07-2.12 (1H, m), 1.77-1.83 (1H, m), 1.62 (4H, broad peak), $0.95(6 \mathrm{H}, \mathrm{t}, J=6.5 \mathrm{~Hz}), 1.01(6 \mathrm{H}, \mathrm{s}), 1.08(6 \mathrm{H}, \mathrm{s}) .{ }^{13} \mathrm{C} \mathrm{NMR}[125$ $\mathrm{MHz}, \mathrm{CDCl}_{3}, \mathrm{SiMe}_{4}, \delta$ (ppm)]: 159.4, 144.9, 138.7, 138.1, 133.2, 131.2, 128.6, 127.9, 125.8, 124.6, 123.9, 121.7, 119.9, 106.4, 91.3, 57.3, 45.3, 39.5, 35.5, 29.9, 28.0, 27.4, 26.4, 22.9, 19.9, 15.7, 11.9. ESI-MS (positive mode, $m / z$ ). Calcd for $\mathrm{C}_{50} \mathrm{H}_{56} \mathrm{~N}_{5} \mathrm{O}: 774.4206(\mathrm{M}$ $+\mathrm{H}$ ). Found: $m / z$ 774.4205. Melting point: $133{ }^{\circ} \mathrm{C}$ (decomposed).

\section{Synthesis of IR-PYR}

The hydrazide $\mathbf{I} 2(25.0 \mathrm{mg}, 0.04 \mathrm{mmol})$ and 2-pyridine carboxaldehyde ( $8.38 \mathrm{mg}, 0.08 \mathrm{mmol}$ ) were dissolved in $1 \mathrm{~mL}$ of DMF and the resulting solution was stirred for $18 \mathrm{~h}$ in room temperature ( 1 drop of acetic acid was added as catalyst). The reaction mixture was concentrated under reduced pressure, and the solid was collected. The crude mixture was separated using column chromatography (using basic Alumina) using hexane/ ethyl acetate $(75: 25)$ mixture. The separated product was further purified using basic alumina preparative layer chromatographic plates, using $\mathrm{CH}_{2} \mathrm{Cl}_{2} / \mathrm{C}_{2} \mathrm{H}_{5} \mathrm{OH}$ (v/v 99 : 1) as eluent to afford the compound IR-PYR as yellowish-green solid (5.5 mg, 20\% yield). ${ }^{1} \mathrm{H}$ NMR $\left[500 \mathrm{MHz}, \mathrm{CDCl}_{3}, \mathrm{SiMe}_{4}, J(\mathrm{~Hz})\right.$, $\delta(\mathrm{ppm})]: 8.5(1 \mathrm{H}, \mathrm{d}, J=5 \mathrm{~Hz}), 8.3(1 \mathrm{H}, \mathrm{d}, J=8 \mathrm{~Hz}), 8.02-8.03$ $(2 \mathrm{H}, \mathrm{m}), 7.69(2 \mathrm{H}, \mathrm{m}), 7.56(1 \mathrm{H}, \mathrm{t}, J=8 \mathrm{~Hz}), 7.42(1 \mathrm{H}, \mathrm{t}, J=7 \mathrm{~Hz})$, $7.13-7.16(1 \mathrm{H}, \mathrm{m}), 7.03(2 \mathrm{H}, \mathrm{t}, J=7.5 \mathrm{~Hz}), 6.94(2 \mathrm{H}, \mathrm{d}, J=7.5$ $\mathrm{Hz}), 6.7(2 \mathrm{H}, \mathrm{t}, J=7.5 \mathrm{~Hz}), 6.45(2 \mathrm{H}, \mathrm{d}, J=8 \mathrm{~Hz}), 6.19(2 \mathrm{H}, \mathrm{d}, J=$ $12 \mathrm{~Hz}), 5.20(2 \mathrm{H}, \mathrm{d}, J=12 \mathrm{~Hz}), 3.40-3.43(4 \mathrm{H}, \mathrm{m}), 3.10-3.14(2 \mathrm{H}$, $\mathrm{m}), 2.62-2.67(2 \mathrm{H}, \mathrm{m}), 2.16-2.20(1 \mathrm{H}, \mathrm{m}), 1.86-1.94(1 \mathrm{H}, \mathrm{m})$, 1.60-1.66 (4H, m), $1.2(6 \mathrm{H}, \mathrm{s}), 1.15(6 \mathrm{H}, \mathrm{s}), 0.93(6 \mathrm{H}, \mathrm{t}, J=7.5$ $\mathrm{Hz}) .{ }^{13} \mathrm{C} \mathrm{NMR}\left[125 \mathrm{MHz}, \mathrm{CDCl}_{3}, \mathrm{SiMe}_{4}, \delta(\mathrm{ppm})\right]: 156.47,149.22$, 148.76, 145.25, 139.02, 136.45, 133.11, 127.55, 126.33, 125.39, 123.83, 122.41, 121.62, 121.26, 120.61, 118.95, 105.72, 91.06, 75.21, 45.22, 44.09, 28.76, 28.28, 26.21, 23.69, 19.83, 11.93. ESIMS (positive mode, $m / z)$. Calcd for $\mathrm{C}_{49} \mathrm{H}_{54} \mathrm{~N}_{5} \mathrm{O}$ : $728.4328(\mathrm{M}+$ $\mathrm{H})$. Found: $m / z$ 728.4323. Melting point: $92-97{ }^{\circ} \mathrm{C}$ (decomposed).

\section{UV-Vis and fluorescence spectral studies}

Stock solutions of various ions $(5.0 \times 10 \mathrm{mM})$ were prepared in deionized water. The stock solutions of ligands $(5.0 \times 10 \mathrm{mM})$ were prepared in DMF. The solution of IR-NCS was then diluted to $10.0 \mu \mathrm{M}$ with methanol/aqueous $1 \times \mathrm{PBS}$ buffer $(\mathrm{pH} 7.4)$ and the solution of IR-PYR was diluted to $10 \mu \mathrm{M}$ with ethanol/ aqueous $1 \times$ PBS buffer $(\mathrm{pH} 7.4 ; 8: 2 \mathrm{v} / \mathrm{v})$. In titration experiments for IR-PYR, each time a $1 \mathrm{~mL}$ solution of the probes $(10$ $\mu \mathrm{M})$ was filled in a quartz optical cell of $1 \mathrm{~cm}$ optical path length, and the metal ion stock solution was added into the quartz optical cell gradually by using a micropipette. Spectral data were recorded $1 \mathrm{~min}$ after the addition of the metal ion. In titration experiments for IR-NCS, separate sample solutions were prepared by addition of increasing amount of $\mathrm{Hg}^{2+}$ ions to 
the probe solution $(10 \mu \mathrm{M})$ and spectral data were recorded within $5 \mathrm{~min}$ after the addition of metal ion. In selectivity experiments, the test samples were prepared by placing appropriate amounts of the corresponding cation stock solution into $1 \mathrm{~mL}$ solution of the probes IR-NCS and IR-PYR $(10 \mu \mathrm{M})$. For fluorescence measurements, excitation was provided at $695 \mathrm{~nm}$, and emission was collected from 725 to $900 \mathrm{~nm}$.

\section{Evaluation of the binding constant for the formation of IR- PYR-Zn complex}

Receptor IR-PYR with an effective concentration of $10 \mu \mathrm{M}$ in an ethanol/aqueous $1 \times$ PBS buffer $(\mathrm{pH} 7.4 ; 8: 2 \mathrm{v} / \mathrm{v})$ was used for the emission titration studies with a $\mathrm{Zn}^{2+}$ metal ion solution. $\mathrm{A}$ stock solution of zinc nitrate, having a concentration of $0.5 \mathrm{mM}$ ethanol/aqueous $1 \times$ PBS buffer ( $\mathrm{pH} 7.4 ; 8: 2 \mathrm{v} / \mathrm{v})$ solution was used. The effective metal ion concentration was varied between 0 and $30 \mu \mathrm{M}$.

The binding constant for the formation of the respective complexes were evaluated using the Benesi-Hildebrand (B-H) plot (eqn (1)). ${ }^{39}$

$$
1 /\left(I-I_{0}\right)=1 /\left\{K\left(I_{\max }-I_{0}\right) C\right\}+1 /\left(I_{\max }-I_{0}\right)
$$

$I_{0}$ is the emission of IR-PYR at $\lambda=780 \mathrm{~nm}, I$ is the observed emission at that particular wavelength in the presence of a certain concentration of the metal ion $(C), I_{\max }$ is the maximum emission value that was obtained at $\lambda=780 \mathrm{~nm}$ during titration with varying metal ion concentration, $K$ is the binding constant and was determined from the slope of the linear plot, and $C$ is the concentration of the $\mathrm{Zn}^{2+}$ ions added during the titration studies.

\section{Finding the detection limit}

The detection limit for $\mathrm{Hg}^{2+}$ was not calculated because the initial changes in fluorescence intensity were not linear (due to intermediate complex formation). The detection limit for $\mathrm{Zn}^{2+}$ and $\mathrm{Cd}^{2+}$ were calculated using the fluorescence titration data. The fluorescence emission spectra of IR-PYR were measured for five times and the standard deviation of blank measurement were achieved. To gain the slope, the ratio of the fluorescence emission at $780 \mathrm{~nm}$ was plotted as a concentration of $\mathrm{Zn}^{2+}$ and $\mathrm{Cd}^{2+}$.

The detection limit was calculated with the following equation:

$$
\text { Detection limit }=3 \sigma / k
$$

where, $\sigma$ is the standard deviation of blank measurement, $k$ is the slope between the ratio of fluorescence emission versus concentration of metal ions.

\section{Computational methods}

Full geometry optimizations were carried out using the density functional theory (DFT) method with Becke-3-Lee-Yang-Parr (B3LYP) exchange functional ${ }^{40}$ for all the molecules. The 6$31 \mathrm{G}^{*}$ basis set was assigned for all $\mathrm{C}, \mathrm{N}, \mathrm{S}, \mathrm{O}$ and $\mathrm{H}$ atoms whereas lanl2dz basis set was assigned for $\mathrm{Zn}$ atom. All calculations were performed with Gaussian 09 program with the help of the GaussView visualization program. ${ }^{41}$

\section{Result and discussion}

\section{Design and synthesis of the NIR probes IR-NCS and IR-PYR}

Controlling the emissive response of a cyanine moiety by spirocyclization is a very recent approach..$^{42}$ Our effort is to modify the spirocyclization approach to design chemosensors for targeting different metal ions by minor tuning of the design. Similar phenomena are also known in rhodamine based spirolactam systems where simple change in the metal binding site of the moiety can completely change the selectivity of the probes. ${ }^{43}$ To the best of our knowledge, this is the first report of a hydrazine functionalized spirolactam capped cyanine probe for sensing multiple metal ions. Hence, this study enables a new strategy for synthesizing NIR probes for metal ions.

In this article we have reported two new molecules IR-NCS and IR-PYR (Scheme 1). In case of IR-NCS we have planned to couple the process of spirolactam ring opening with the stoichiometric and irreversible $\mathrm{Hg}^{2+}$-induced conversion of thiosemicarbazides to 1,3,4-oxadiazoles (Scheme 2). ${ }^{44}$ We have expected that this would work as the foundation for a novel $\mathrm{Hg}^{2+}$ selective chemodosimeter. The cyanine derivative IR-NCS seemed to be perfect for this application since the thiosemicarbazide moiety of IR-NCS can be easily liberated to form the oxadiazole in presence of $\mathrm{Hg}^{2+}$ ions, which in terms will induce the ring opening of the spirolactam unit.

In case of IR-PYR we have designed a pyridine functionalised metal binding site, which along with the pyridine nitrogen, the lactam oxygen and the $\mathrm{sp}^{2}$ hybridized imine nitrogen provides the necessary support for binding metal ions. This kind of metal binding site constituting three donor atoms is well known for binding transition metal ions like $\mathrm{Cu}^{2+} / \mathrm{Zn}^{2+} / \mathrm{Cd}^{2+}$ etc. ${ }^{45}$ We have expected that the binding of specific metal ions with IR-PYR will trigger the opening of spirolactam ring of the cyanine
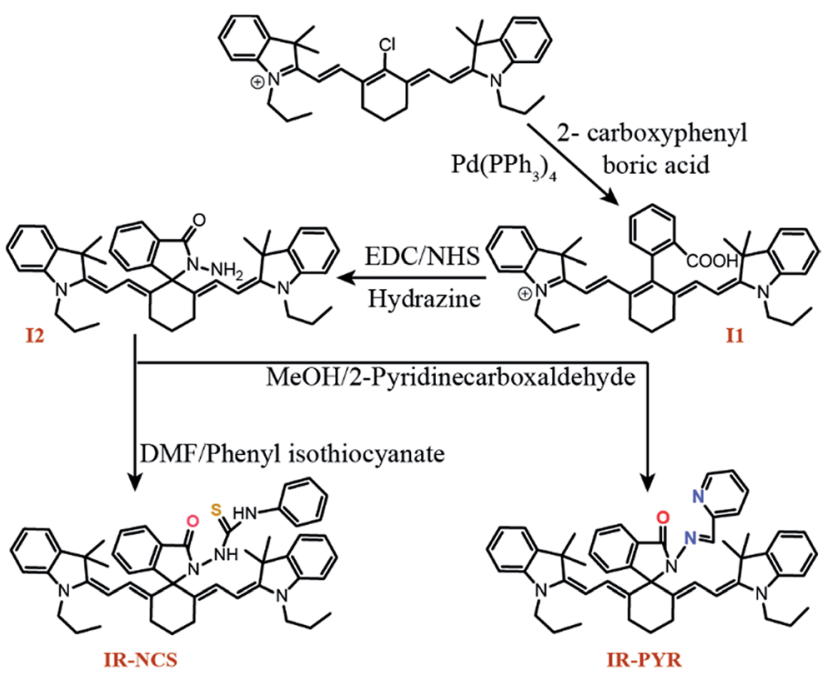

Scheme 1 Synthetic scheme for the probes IR-NCS and IR-PYR 


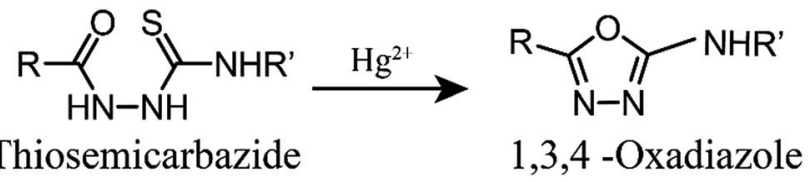

Scheme $2 \mathrm{Hg}^{2+}$ induced oxadiazole formation.

derivative, which can be easily detected through changes in absorbance and fluorescence property of the solution.

The synthesis of compound I1, I2, IR-NCS and IR-PYR is shown in Scheme 1. The overall synthesis of the probes is very simple involving three easy steps. The first step is the synthesis of I1 by the Suzuki-Miyaura coupling, where we have attached benzoic acid moiety to the cyanine unit by refluxing cyanine chloride (IR-780) with carboxyphenylboric acid in the presence of $\mathrm{Pd}\left(\mathrm{PPh}_{3}\right)_{4}$ in $\mathrm{DMF} / \mathrm{H}_{2} \mathrm{O}$. The second step is the formation of the hydrazide, where I1 was first activated with $N$-hydroxysuccinimide (NHS) followed by reacting with hydrazine hydrate. The highly reactive amine group present in the hydrazine gives extra flexibility to the system and in the third step the metal selective sites were connected with the fluorophore through the free amine group of the hydrazide. The structure of all the compounds were fully characterised by ${ }^{1} \mathrm{H}$ NMR, ${ }^{13} \mathrm{C}$ NMR and MS-ESI spectroscopic studies.

\section{UV-Vis spectroscopy of IR-NCS and IR-PYR}

The photo-physical data of the compounds in methanol $(\mathrm{MeOH})$ are compiled in Table S1. $\dagger$

Our aim was to study the metal-ligand binding induced opening of the spirolactam ring of IR-NCS and generation of the cyanine form. This structural change can be manifested in the electronic and fluorescence spectral patterns. UV-Vis spectra of IR-NCS recorded in methanol/aqueous PBS buffer indicated an absorption hump around 770-825 nm (Fig. 1a), absorbance around $780 \mathrm{~nm}$ is indicative of the presence of conjugated cyanine moiety in the solution, which might be due to the existence of a reversible equilibrium between the nonconjugated IR-NCS and the ring opened IR-NCS with conjugated cyanine backbone (Scheme 3). The selectivity of IR-NCS was checked in presence of various metal ions $\left(\mathrm{Na}^{+}, \mathrm{Mg}^{2+}, \mathrm{Cr}^{3+}\right.$,
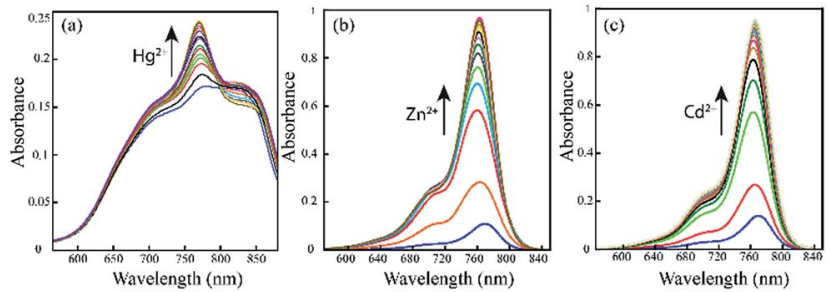

Fig. 1 (a) UV-Vis titration spectra of IR-NCS $(10 \mu \mathrm{M})$ upon incremental addition of $\mathrm{Hg}^{2+}$ ions in $\mathrm{CH}_{3} \mathrm{OH}$ /aqueous PBS buffer $(1 \times, \mathrm{pH} 7.4 ; 3: 7 \mathrm{v} / \mathrm{v})$. (b) UV-Vis titration spectra of IR-PYR $(10 \mu \mathrm{M})$ upon incremental addition of $\mathrm{Zn}^{2+}$ ions in $\mathrm{C}_{2} \mathrm{H}_{5} \mathrm{OH}$ /aqueous PBS buffer (1x, pH 7.4; $\left.8: 2 \mathrm{v} / \mathrm{v}\right)$. (c) UVVis titration spectra of IR-PYR $(10 \mu \mathrm{M})$ upon incremental addition of $\mathrm{Cd}^{2+}$ ions in $\mathrm{C}_{2} \mathrm{H}_{5} \mathrm{OH}$ /aqueous PBS buffer (1×, $\left.\mathrm{pH} 7.4 ; 8: 2 \mathrm{v} / \mathrm{v}\right)$.

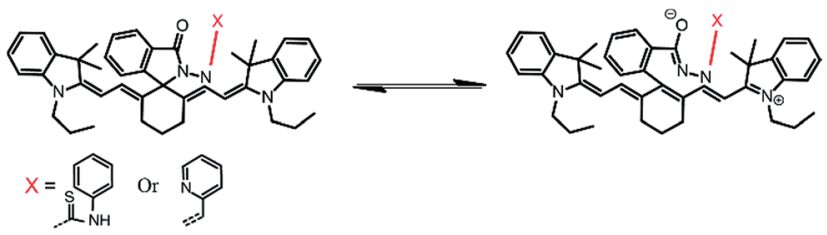

Scheme 3 Equilibrium between the closed and open form of IR-NCS or IR-PYR.

$\mathrm{Hg}^{2+}, \mathrm{Cu}^{2+}, \mathrm{Zn}^{2+}, \mathrm{Fe}^{3+}, \mathrm{Fe}^{2+}, \mathrm{Co}^{2+}, \mathrm{Ni}^{2+}, \mathrm{Cd}^{2+}$, and $\left.\mathrm{Al}^{3+}\right) . \mathrm{A}$ significant change in the UV-Vis spectral pattern of IR-NCS was observed only in presence of $\mathrm{Hg}^{2+}$ ions, among all the other metal ions used (Fig. S1a†). During sequential titration with increasing concentration of $\mathrm{Hg}^{2+}$ ions ( 0 equiv. to 3 equiv. of $\mathrm{Hg}^{2+}$ ) a sharp absorption peak appeared around $769 \mathrm{~nm}$ (Fig. 1a). Additionally it is also observed that the initial absorbance peak of IR-NCS is broad, indicative of multiple species present in the solution. Possibility of the existence of more than one species in the solution of IR-NCS was further discussed in the Theoretical study section.

We have also performed metal dependent UV-Vis studies with IR-PYR, in this case we have found that the ligand itself shows some absorbance around $770 \mathrm{~nm}$, which is expected due to the reversible equilibrium between the closed and open forms of IR-PYR (Scheme 3), similar to our observation in IRNCS. The selectivity of the ligand is checked in presence of various metal ions $\left(\mathrm{Na}^{+}, \mathrm{Mg}^{2+}, \mathrm{Mn}^{2+}, \mathrm{Hg}^{2+}, \mathrm{Cu}^{2+}, \mathrm{Zn}^{2+}, \mathrm{Fe}^{3+}, \mathrm{Fe}^{2+}\right.$, $\mathrm{Co}^{2+}, \mathrm{Ni}^{2+}, \mathrm{Cd}^{2+}$, and $\left.\mathrm{Al}^{3+}\right)$. A significant change in the UV-Vis spectral pattern was observed selectively in presence of $\mathrm{Cd}^{2+}$ and $\mathrm{Zn}^{2+}$ ions (Fig. S1b†).

Upon continuous addition of $\mathrm{Zn}^{2+} / \mathrm{Cd}^{2+}$ metal ions absorbance at $770 \mathrm{~nm}$ increases sharply forming an absorption band characteristic of a conjugated cyanine moiety (Fig. 1b and c).

\section{Fluorescence spectroscopic studies}

The selectivity of the synthesized probes IR-NCS and IR-PYR towards different metal ions $\left(\mathrm{Na}^{+}, \mathrm{Mg}^{2+}, \mathrm{Cr}^{3+}, \mathrm{Hg}^{2+}, \mathrm{Cu}^{2+}, \mathrm{Zn}^{2+}\right.$, $\mathrm{Fe}^{3+}, \mathrm{Fe}^{2+}, \mathrm{Co}^{2+}, \mathrm{Ni}^{2+}, \mathrm{Cd}^{2+}$, and $\mathrm{Al}^{3+}$ in $\mathrm{CH}_{3} \mathrm{OH} /$ aqueous PBS
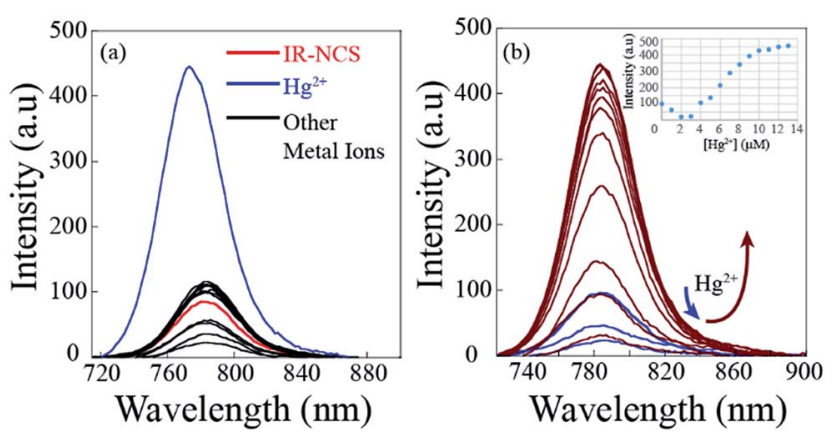

Fig. 2 (a) Fluorescence spectra of IR-NCS in $\mathrm{CH}_{3} \mathrm{OH}$ /aqueous PBS buffer $(1 \times, \mathrm{pH} 7.4 ; 4: 6 \mathrm{v} / \mathrm{v})$ in presence of various metal ions (10 equivalent). (b) Fluorescence titration spectra of IR-NCS (10 $\mu \mathrm{M})$ upon incremental addition ( 0 to 1.4 equivalent) of $\mathrm{Hg}^{2+}$ ions in $\mathrm{CH}_{3} \mathrm{OH}$ / aqueous PBS buffer (1x, pH 7.4; $4: 6 \mathrm{v} / \mathrm{v})$. 
buffer) were also studied by fluorescence emission spectroscopy. As shown in Fig. 2a, a solution of IR-NCS $(10 \mu \mathrm{M})$ displayed a low intensity emission maxima near $785 \mathrm{~nm}$ when excited at $695 \mathrm{~nm}$. Addition of $\mathrm{Hg}^{2+}$ ions to this probe solution induced a dramatic increase in the fluorescence intensity. It can also be witnessed from Fig. 2a that the metal dependent switchON response of IR-NCS is entirely selective towards $\mathrm{Hg}^{2+}$ ions, and no significant change in emission intensity occurred even in the presence of excess of other metal ions. To gain an insight of the properties of IR-NCS as a sensor for $\mathrm{Hg}^{2+}$ ions, a titration of the chemosensor was performed with sequential addition of $\mathrm{Hg}^{2+}$ ions. As shown in Fig. $2 \mathrm{~b}$ the fluorescence intensity of the solution containing $10 \mathrm{mM}$ of IR-NCS was enhanced (with an initial decrease) with increasing concentration of $\mathrm{Hg}^{2+}$ ions, the initial decrease in fluorescence intensity was maybe due to the formation of an intermediate complex between the fluorophore and the heavy metal ion $\left(\mathrm{Hg}^{2+}\right)$ (Scheme 4$) .{ }^{46}$ The fluorescence titration also confirmed that IR-NCS exhibits high sensitivity toward $\mathrm{Hg}^{2+}$. The saturation behavior of the emission intensity of IR-NCS after addition of 1 equiv. of $\mathrm{Hg}^{2+}$ reveals that the $\mathrm{Hg}^{2+}$ chemosensor/chemodosimeter has a $1: 1$ stoichiometry.

The mechanism of chemodosimetric response of IR-NCS is further confirmed by ESI-MS studies of the sensor solution in presence of $\mathrm{Hg}^{2+}$ ions (ESI Fig. S14 $\dagger$ ), the molecular ion peak at $\mathrm{m} / \mathrm{z} 740.4316$ proves the presence of desired product IR-HGP in the solution.

The change in emission spectra of IR-NCS in presence of $\mathrm{Hg}^{2+}$ can be explained by the chemical reaction shown in Scheme 4. Reaction of $\mathrm{Hg}^{2+}$ ions with the chemodosimeter breaks the spirolactam ring with the formation of IR-HGP as a product. As shown in Scheme 4, formation of the product IRHGP also caused the reappearance of the positive charge on the nitrogen atom resulting in the generation of a highly conjugated cyanine backbone. Thus, with increasing concentration of $\mathrm{Hg}^{2+}$ ions the concentration of cyanine moiety in the solution also increases, consequently a sharp change in the absorption as well as emission spectra is observed.

In case of IR-PYR the excitation of the initial solution at $695 \mathrm{~nm}$ wavelength shows an emission peak near $780 \mathrm{~nm}$. The low intensity of the peak supports the fact that in absence of metal ions the molecule remains predominantly in the spirolactam form. Addition of $\mathrm{Zn}^{2+} / \mathrm{Cd}^{2+}$ ions to the solution containing IR-PYR induces a sharp increase in fluorescence

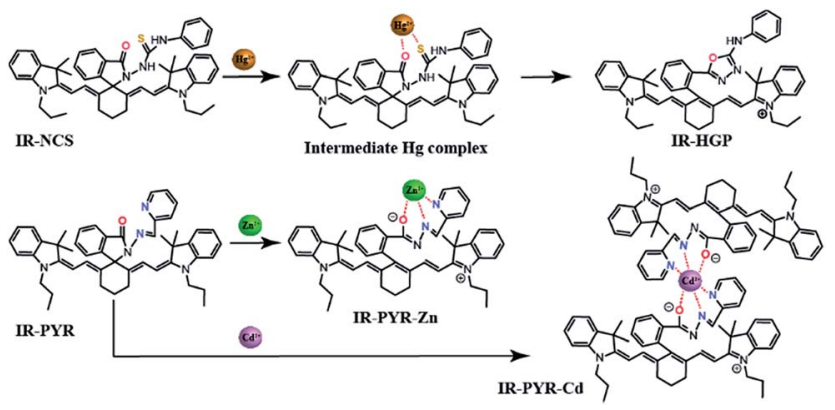

Scheme 4 Metal sensing mechanism of IR-NCS and IR-PYR.
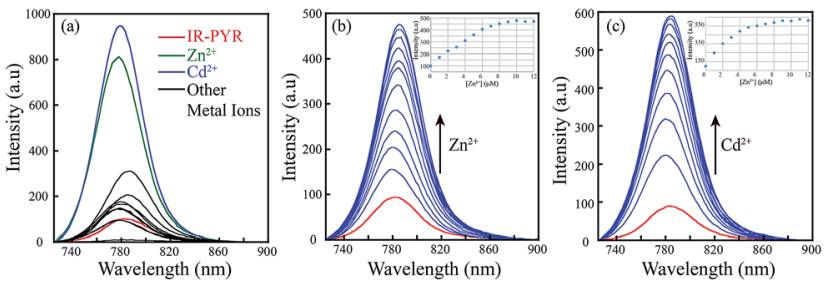

Fig. 3 (a) Fluorescence spectra of IR-PYR in $\mathrm{C}_{2} \mathrm{H}_{5} \mathrm{OH}$ /aqueous PBS buffer $(1 \times, \mathrm{pH} 7.4 ; 8: 2 \mathrm{v} / \mathrm{v})$ in presence of various metal ions (10 equivalent). (b) Fluorescence titration spectra of IR-PYR $(10 \mu \mathrm{M})$ upon incremental addition ( 0 to 1.2 equivalent) of $\mathrm{Zn}^{2+}$ ions in $\mathrm{C}_{2} \mathrm{H}_{5} \mathrm{OH}$ / aqueous PBS buffer $(1 \times, \mathrm{pH} 7.4 ; 8: 2 \mathrm{v} / \mathrm{v})$. (c) Fluorescence titration spectra of IR-PYR $(10 \mu \mathrm{M})$ upon incremental addition ( 0 to 1.2 equivalent) of $\mathrm{Cd}^{2+}$ ions in $\mathrm{C}_{2} \mathrm{H}_{5} \mathrm{OH}$ /aqueous PBS buffer (1×, $\left.\mathrm{pH} 7.4 ; 8: 2 \mathrm{v} / \mathrm{v}\right)$.

intensity near $780 \mathrm{~nm}$. Increase in the absorption spectral band near $770 \mathrm{~nm}$ and the emission band near $780 \mathrm{~nm}$ on binding to $\mathrm{Zn}^{2+} / \mathrm{Cd}^{2+}$ suggested opening of the spirolactam ring in IR-PYR on metal ion coordination. As shown in Fig. 3a the metal-chemosensor binding induced ring opening of IR-PYR and the formation of conjugated cyanine moiety is selective towards $\mathrm{Zn}^{2+}$ and $\mathrm{Cd}^{2+}$ ions and shows very weak response for other tested metal ions $\left(\mathrm{Na}^{+}, \mathrm{Mg}^{2+}, \mathrm{Mn}^{2+}, \mathrm{Hg}^{2+}, \mathrm{Cu}^{2+}, \mathrm{Zn}^{2+}, \mathrm{Fe}^{3+}, \mathrm{Fe}^{2+}\right.$, $\mathrm{Co}^{2+}, \mathrm{Ni}^{2+}, \mathrm{Cd}^{2+}$, and $\left.\mathrm{Al}^{3+}\right)$. To further understand the metal sensing mechanism of IR-PYR as a sensor for $\mathrm{Zn}^{2+}$ and $\mathrm{Cd}^{2+}$ ions, a titration of the solution containing IR-PYR was performed with increasing concentration of $\mathrm{Zn}^{2+}$ and $\mathrm{Cd}^{2+}$ ions respectively. As shown in Fig. $3 \mathrm{~b}$ and $\mathrm{c}$ the emission intensity of a $10 \mu \mathrm{M}$ solution of IR-PYR was enhanced with sequential addition of $\mathrm{Zn}^{2+}$ and $\mathrm{Cd}^{2+}$ ions, in both the cases the ligand exhibited a high sensitivity towards the corresponding metal ions, with near about 6 folds increase of its fluorescence intensity upon addition of 1.2 equivalent of metal ions.

The stoichiometry of the complex formed between IR-PYR and metal ions was established with the help of Job's plot. The complex formed between $\mathrm{Zn}^{2+}$ and IR-PYR is found to be $1: 1$ in stoichiometry (Fig. S6 $\dagger$ ), whereas the complex formed between $\mathrm{Cd}^{2+}$ and IR-PYR is initially $1: 2$ in nature, but tends to form a $1: 1$ complex in presence of excess metal ions in the solution (Fig. $\mathrm{S} 7 \dagger$ ). The $1: 1$ stoichiometry of both complexes was further proved from the ESI-MS studies. The molecular-ion peak obtained at $m / z 853.3376$ in the mass spectrum is related to the mass of [IR-PYR $+\mathrm{Zn}^{2+}+\mathrm{NO}_{3}$ ] (ESI Fig. S15 $\dagger$ ) and the molecular ion peak at $m / z 903.3183$ is related to the mass of [IR-PYR $+\mathbf{C d}^{2+}$ $+\mathrm{NO}_{3}$ ] (ESI Fig. S16 $\dagger$ ). Binding constant for the $\mathrm{Zn}$-complex was calculated using Benesi-Hildebrand method, which was found to be $1.9 \times 10^{6} \mathrm{M}^{-1}$. The detection limit of IR-PYR for $\mathrm{Zn}^{2+}$ and $\mathrm{Cd}^{2+}$ ions was found to be $3.3 \times 10^{-8} \mathrm{M}(33 \mathrm{nM})$ and $4.7 \times$ $10^{-8} \mathrm{M}(47 \mathrm{nM})$ respectively.

\section{Theoretical studies}

For a theoretical assessment of the optical response of IR-NCS and IR-PYR toward specific metal ions Density Functional Theory (DFT) based calculations were performed using Gaussian 09 package. DFT calculations of the probes also gave us a clear idea about their geometries. The findings from the 
optical spectroscopic and mass spectrometric studies indicated that IR-NCS undergoes a cyclization reaction in presence of $\mathrm{Hg}^{2+}$ ions, which induced breaking of the spirolactam ring to form a new compound IR-HGP (Scheme 4). Thus, the geometry of both IR-NCS and IR-HGP was optimized. The DFT optimization of IR-NCS revealed that the spirolactam ring of IR-NCS stays perpendicular to the heptamethine cyanine backbone and the $\mathrm{C}=\mathrm{S}$ double bond prefers to align in the opposite direction to the carbonyl $\mathrm{C}=\mathrm{O}$ bond (Fig. 4).

It was also noticed that the planarity of the cyanine backbone in IR-NCS is decreased compared to that of the free acid (I1), which may be attributed to the lack of conjugation in the former. On the other hand in case of IR-HGP the newly formed oxadiazole ring stays completely perpendicular to the cyanine backbone and due to the formation of the conjugated structure the planarity in the system is regained (Fig. S $3 \dot{\dagger}$ ).

As the electronic spectra of both IR-NCS and IR-HGP are mainly generated from the electronic transition from HOMO to LUMO, we have also calculated the corresponding HOMO and LUMO energies. The HOMO-LUMO energy difference of IR-NCS is $3.38455381 \mathrm{eV}$ whereas the respective energy difference in case of IR-HGP is $2.04548087 \mathrm{eV}$. The steep decrease in energy difference values explains the increase in absorbance of the NIR band $(770 \mathrm{~nm})$ in presence of $\mathrm{Hg}^{2+}$ ions.

We have also used theoretical calculations to understand the equilibrium between the ring-opened and ring-closed form of IR-NCS. As shown in Fig. 5 a we have assumed that the O-atom in ring-opened form of IR-NCS can either be in a protonated state or in a deprotonated state in aqueous solution. The broadness of the UV-Vis peak over a wide range also indicated that multiple species were present in the solution. Thus to validate

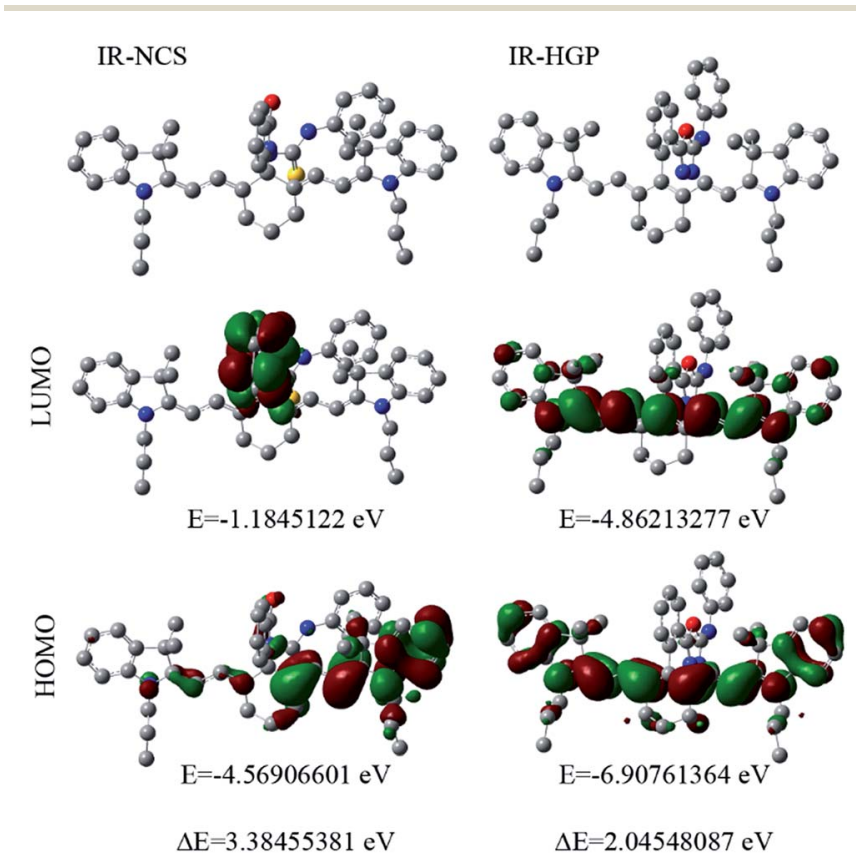

Fig. 4 Theoretically optimized structures of IR-NCS and IR-HGP and energy diagrams of HOMO and LUMO orbitals of IR-NCS and IR-HGP calculated at the DFT level using a B3LYP/6-31G*. All protons are removed from the image for clarity.

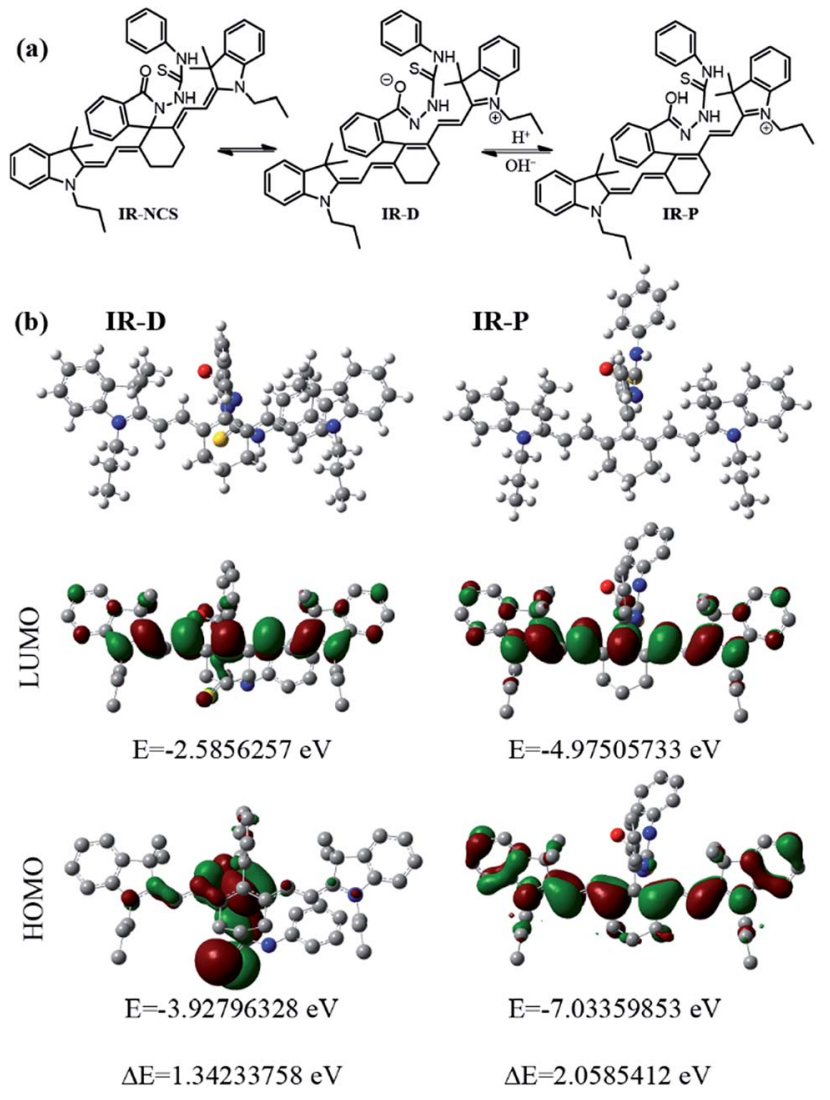

Fig. 5 (a) Equilibrium between the probable species present in the solution of IR-NCS. (b) Theoretically optimized structures of IR-D and $\mathrm{IR}-\mathrm{P}$ and the corresponding energy diagrams of HOMO and LUMO orbitals calculated at the DFT level using a B3LYP/6-31G*. All protons are removed from the image for clarity.

our experimental results we have calculated the HOMO and LUMO energies of the protonated and deprotonated species viz. IR-P and IR-D. For IR-P the HOMO-LUMO energy difference of the geometrically optimized structure is found to be $2.0585412 \mathrm{eV}$ (Fig. 5b), which is similar to the HOMO-LUMO energy gap of IR-HGP.

The similarity between the corresponding energy gaps of IR$\mathrm{P}$ and IR-HGP confirms that the hump near $770 \mathrm{~nm}$ in an aqueous solution of IR-NCS is due to the presence of IR-P in the solution. On the other hand the corresponding energy difference of IR-D was found to be $1.34233758 \mathrm{eV}$ (Fig. 5b). The relatively small HOMO-LUMO energy gap of IR-D indicates that the hump in the longer wavelength region (over $800 \mathrm{~nm}$ ) of the absorbance spectra is due to the presence of IR-D in the aqueous solution of IR-NCS. Furthermore we have confirmed these facts again by recording absorbance of IR-NCS respectively in an acidic and a basic medium. In a basic medium of $\mathrm{pH}$ 9 most of the ring opened IR-NCS molecules are in IR-D form and the absorbance spectra show a broad peak with a prominent hump in the longer wavelength region (over $800 \mathrm{~nm}$ ), whereas in acidic medium of pH 4 most of the ring opened IRNCS molecules are in IR-P form and the absorbance spectra show a sharp peak at relatively shorter wavelength (near 770 nm) (ESI, Fig. S5 †). 
In case of IR-PYR, we have confirmed from the Job's plot analysis and mass spectrometric studies that a $1: 1$ complex is formed in presence of $\mathrm{Zn}^{2+}$ ions, whereas both $1: 2$ and $1: 1$ complexes were possible in presence of $\mathrm{Cd}^{2+}$ ions. Thus, for the sake of simplicity we have pursued the geometry optimization of IR-PYR and its Zn complex (IR-PYR-Zn).

Similar to IR-NCS, IR-PYR also showed lesser planarity of the non-conjugated cyanine backbone and in both the cases the spirolactam unit is perpendicular to the heptamethine chain. In presence of $\mathrm{Zn}^{2+}$ ions the electron pairs from carbonyl-O, imine$\mathrm{N}$ and pyridine- $\mathrm{N}$ participate in the binding event (Fig. 6).

After chelation with the $\mathrm{Zn}^{2+}$ ion, the newly formed IR-PYRZn complex retained a more planar geometry (cyanine backbone) than its precursor IR-PYR (Fig. S4 $\dagger$ ). The HOMO-LUMO energy difference of IR-PYR is $3.13774642 \mathrm{eV}$ whereas the respective energy difference in case of IR-PYR-Zn is 2.04711354. Similar to the probe IR-NCS in this case also sharp decrease in the energy difference value is consistent with the result obtained from UV-Vis spectral analysis. Furthermore in both of the cases we have noticed that after the formation of IR-HGP and IR-PYR-Zn atomic contribution to the HOMO/LUMO is solely from the cyanine backbone, which again verifies our assumption that the increase in UV-Vis absorbance after metal recognition is observed due to the presence of highly conjugated cyanine unit in the system.

\section{Metal-ion competition studies}

The absorption and emission response of IR-PYR and IR-NCS in presence of individual metal ions had shown a notable selectivity for $\mathrm{Zn}^{2+} / \mathrm{Cd}^{2+}$ and $\mathrm{Hg}^{2+}$ metal ions. However, the most significant criterion of a chemosensor is its ability to recognize the target analyte in a complex environment of other competing analytes. This hypothesis has been validated by testing the
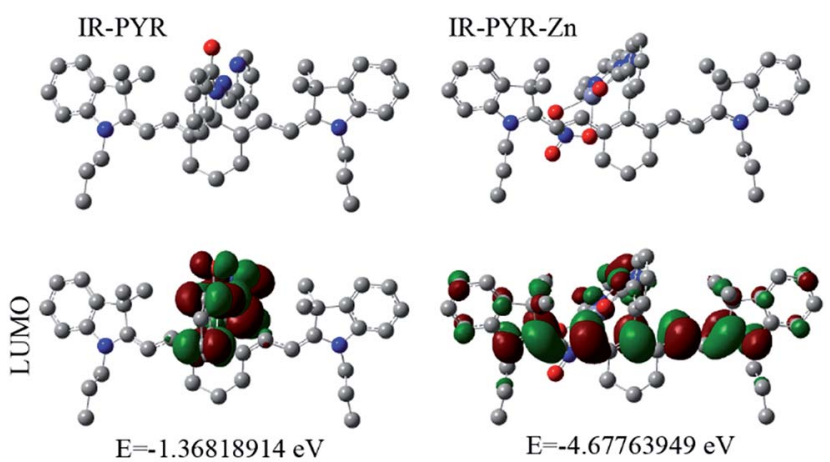

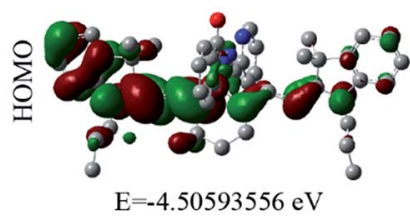

$\Delta \mathrm{E}=3.13774642 \mathrm{eV}$

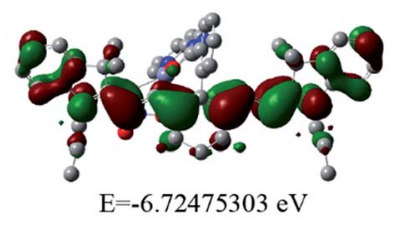

$\Delta \mathrm{E}=2.04711354 \mathrm{eV}$
Fig. 6 Theoretically optimized structures of IR-PYR and IR-PYR-Zn (nitrate as a counter anion) and the corresponding energy diagrams of HOMO and LUMO orbitals calculated at the DFT level using a B3LYP/ 6-31G*. All protons are removed from the image for clarity. selectivity of IR-NCS and IR-PYR in presence of various cations, which can interfere with the sensing of $\mathrm{Zn}^{2+} / \mathrm{Cd}^{2+}$ and $\mathrm{Hg}^{2+}$ metal ions. The fluorescence response of IR-NCS in presence of $\mathrm{Hg}^{2+}$ metal ions was nearly unchanged even after addition of 5 equivalents of competing metal ions $\left(\mathrm{Mg}^{2+}, \mathrm{Cu}^{2+}, \mathrm{Mn}^{2+}, \mathrm{Zn}^{2+}\right.$, $\mathrm{Fe}^{2+}, \mathrm{Co}^{2+}, \mathrm{Ni}^{2+}$ and $\mathrm{Al}^{3+}$ ) Fig. 7a. On the other hand IR-PYR shows significant interference only in presence of $\mathrm{Cu}^{2+}$ ions, which might have a better binding compatibility with the ligand, thus in presence of paramagnetic $\mathrm{Cu}^{2+}$ ions the emission intensity is completely quenched ${ }^{46}$ and did not re-appear with the addition of $\mathrm{Zn}^{2+} / \mathrm{Cd}^{2+}$ ions (Fig. 7b).

\section{Cell imaging studies}

The importance of any chemosensing probe is evaluated by its potential to detect the analyte inside living systems like cells or organism. The effective detection of analyte inside living cells proves the ability of the probe to work within a complex environment. As evident cellular intake of any chemosensor crucially depends on the solubility of the probe. The plasma membrane of cells is lipophilic in nature whereas the intracellular environment is of opposite nature, thus molecular probe must have an optimum solubility which allow it to get pass the lipophilic membrane. Along with the solubility, the charge character of a probe also plays an important role. A neutral molecule can easily diffuse through the membrane whereas a charged molecule may not readily diffuse through membranes, instead they show a tendency to accumulate in subcellular compartments. ${ }^{47}$

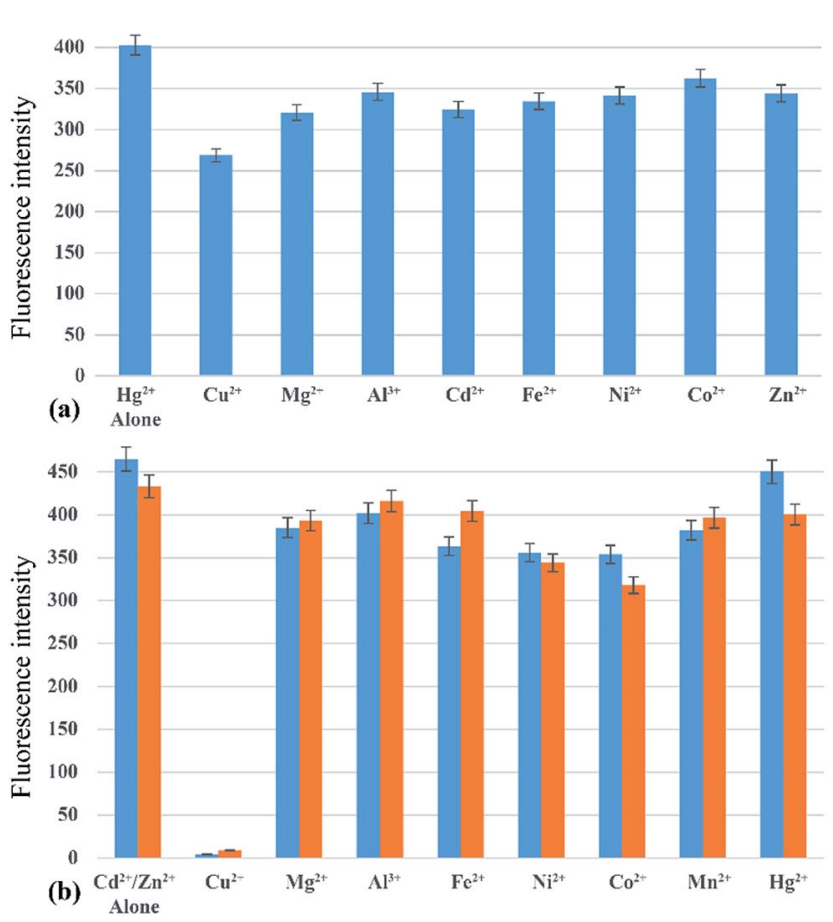

Fig. 7 (a) Normalized fluorescence responses of IR-NCS $(10 \mu \mathrm{M})$ in presence of 5 equivalent of various metal ions and after subsequent addition of 1 equivalent $\mathrm{Hg}^{2+}$ ions. (b) Normalized fluorescence responses of IR-PYR $(10 \mu \mathrm{M})$ in presence of 5 equivalent of various metal ions and after subsequent addition of 1 equivalent $\mathrm{Cd}^{2+}$ (blue bars) or $\mathrm{Zn}^{2+}$ (orange bars) metal ions. 


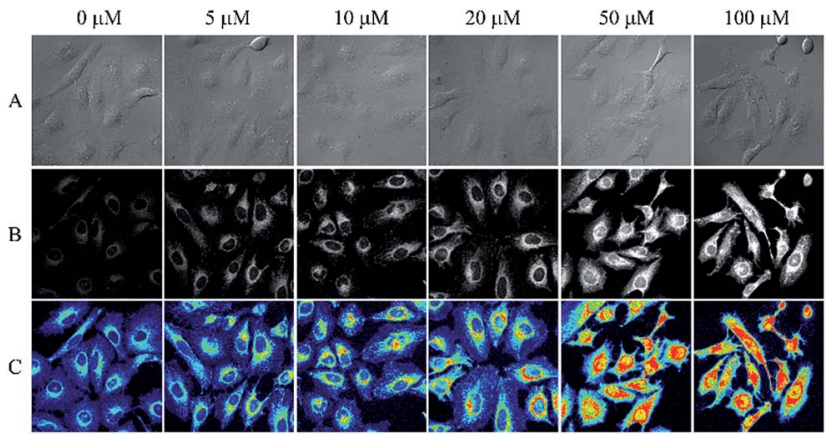

Fig. 8 Each column from left to right represents the confocal microscopic images of HeLa cells (pre-treated with $20 \mu \mathrm{M}$ IR-NCS) after addition of $0-100 \mu \mathrm{M} \mathrm{Hg}^{2+}$ ions. Row (A) represents the differential interference contrast (DIC) images. Row (B) represent the fluorescence images. Row (C) represents the pseudo-colored images, blue to red color is assigned to fluorescence intensity from 0 to 1500 .

In this study both of our ligands were primarily uncharged but form a charged species when reacted with selective metal ions. Given the suitable water solubility of IR-NCS and significant physiological implications of cellular mercury, we were motivated to investigate the ability of IR-NCS for detecting intracellular levels of mercury. As evident from our solution based spectroscopic studies, IR-NCS undergoes a chemical reaction in presence of $\mathrm{Hg}^{2+}$ ions to form a new molecule with increase in fluorescence intensity. Our aim was to determine if the chemical reaction and the corresponding change in fluorescence intensity is prominent enough to be determined inside living human cells by confocal microscopy (Fig. 8). When the HeLa cells were primarily treated with $20 \mu \mathrm{M}$ of IR-NCS, the cells show very mild fluorescence intensity. In the next step we have gradually increased the concentration of $\mathrm{Hg}^{2+}$ ions from $5 \mu \mathrm{M}$ to $100 \mu \mathrm{M}$. As shown in Fig. 8 the cells start to show significant increment in fluorescence intensity even when the mercury concentration is as low as $5 \mu \mathrm{M}$, indicating selective sensing of $\mathrm{Hg}^{2+}$ ions in complex cellular environment.

Interestingly, the increase in fluorescence intensity inside the cells is consistent with the increase in $\mathrm{Hg}^{2+}$ metal ion concentration, thus along with the sensing of mercury ions inside cells a prediction about the extent of contamination can also be done. The uniform distribution of fluorescence across the intracellular region suggests that IR-NCS can pass through the cell membrane and permeate the cells and upon further addition of $\mathrm{Hg}^{2+}$ ions the probe IR-NCS undergoes a ring opening reaction to produce IR-HGP as a product. As the concentration of IR-HGP inside cells increases the corresponding fluorescence intensity also increases. It is also noteworthy that the typical morphological trait of HeLa cells were retained throughout the experiment, which indicates that the probe IR-NCS and the product IR-HGP are not cytotoxic to the HeLa cells.

\section{Conclusion}

In summary, we have developed a new technique to design chemosensors for metal ions which are easily modifiable for targeting different metals ions. To verify our system we have synthesised two compounds IR-NCS and IR-PYR which show significant changes in their fluorescence and absorbance spectra in presence of selective metal ions. We found that in the case of IR-NCS, the $\mathrm{Hg}^{2+}$ ion selective response was due to a chemodosimetric reaction of the probe with $\mathrm{Hg}^{2+}$ ions to form a new compound IR-HGP, which triggers the opening of the spirolactam ring in IR-NCS to form a conjugated cyanine dye. On the other hand, the $\mathrm{Zn}^{2+} / \mathrm{Cd}^{2+}$ metal ion selective response of IR-PYR was found to be completely due to the formation of a coordination complex between the probe and the metal ion, which induces the ring opening of the spirolactam cycle and subsequently increases the emission intensity in the NIR spectral region. We have also used DFT based calculation techniques as supporting evidences of our experimental results. As the probe IR-NCS has an optimum solubility in aqueous medium so we have used it for intracellular detection of $\mathrm{Hg}^{2+}$ ions, we found that the cells pre-treated with the probe display significant increase in emission intensity in presence of $\mathrm{Hg}^{2+}$ ions under the confocal microscope. We expect that this new technique can be further applied for developing NIR sensors for various environmentally and biologically important metal ions.

\section{Acknowledgements}

CK acknowledge JSPS for the research grant and his alma mater IIT Guwahati for the Gaussian 09 package.

\section{References}

1 T. R. A. Vandenbroucke, P. Emsbo, A. Munnecke, N. Nuns, L. Duponchel, K. Lepot, M. Quijada, F. Paris, T. Servais and W. Kiessling, Nat. Commun., 2015, 6, 7966, DOI: 10.1038/ ncomms8966.

2 S. J. Lippard and J. M. Berg, Principles of Bioinorganic Chemistry, University Science Books, Mill Valley, CA, 1994.

3 A. T. Aron, K. M. Ramos-Torres, J. A. Cotruvo Jr and C. J. Chang, Acc. Chem. Res., 2015, 48, 2434-2442.

4 N. Shao, Y. Zhang, S. M. Cheung, R. H. Yang, W. H. Chan, T. Mo, K. A. Li and F. Liu, Anal. Chem., 2005, 77, 72947303; D. W. Domaille, E. L. Que and C. J. Chang, Nat. Chem. Biol., 2008, 4, 168-175; K. M. K. Swamy, S. K. Ko, S. K. Kwon, H. N. Lee, C. Mao, J. M. Kim, K. H. Lee, J. Kim, I. Shin and J. Yoon, Chem. Commun., 2008, 5915-5917.

5 E. Kimura, Pure Appl. Chem., 1986, 58, 1461-1466; Z. Zhou and C. J. Fahrni, J. Am. Chem. Soc., 2004, 126, 8862-8863; Y. Zhou, F. Wang, Y. Kim, S. J. Kim and J. Yoon, Org. Lett., 2009, 11, 4442-4445.

6 L. Fabbrizzi, M. Licchelli, P. Pallavicini, A. Perotti and D. Sacchi, Angew. Chem., 1994, 106, 2051-2053; E. L. Que, D. W. Domaille and C. J. Chang, Chem. Rev., 2008, 108, 1517-1549.

7 J. Cody and C. J. Fahrni, Tetrahedron, 2004, 60, 11099-11107; X. Qi, E. J. Jun, L. Xu, S. J. Kim, J. S. J. Hong, Y. J. Yoon and J. Y. Yoon, J. Org. Chem., 2006, 71, 2881-2884; Y. Xiang, A. J. Tong and Y. Ju, Org. Lett., 2006, 8, 2863-2866; G. K. Li, Z. X. Xu, C. F. Chen and Z. T. Huang, Chem. Commun., 
2008, 1774-1776; M. X. Yu, M. Shi, Z. G. Chen, F. Y. Li, X. X. Li, Y. H. Gao, J. Xu, H. Yang, Z. G. Zhou, T. Yi and C. H. Huang, Chem.-Eur. J., 2008, 14, 6892-6900.

8 S. Goswami, D. Sen and N. K. Das, Org. Lett., 2010, 12, 856859; Z. Xu, J. Yoon and D. R. Spring, Chem. Commun., 2010, 46, 2563-2565; K. Kaur and S. Kumar, Dalton Trans., 2011, 40, 2451-2458; K. C. Ko, J. S. Wu, H. J. Kim, P. S. Kwon, J. W. Kim, R. A. Bartsch, J. Y. Lee and J. S. Kim, Chem. Commun., 2011, 47, 3165-3167.

9 R. Martinez, F. Zapata, A. Caballero, A. Espinosa, A. Tarraga and P. Molina, Org. Lett., 2006, 8, 3235-3238; E. Sanna, L. Martinez, C. Rotger, S. Blasco, J. Gonzalez, E. GarciaEspana and A. Costa, Org. Lett., 2010, 12, 3840-3843; A. F. Chaudhry, M. Verma, M. T. Morgan, M. M. Henary, N. Siegel, J. M. Hales, J. W. Perry and C. J. Fahrni, J. Am. Chem. Soc., 2010, 132, 737-747; M. Verma, A. F. Chaudhry and C. J. Fahrni, Org. Biomol. Chem., 2010, 8, 363-370.

10 Y. Zheng, Q. Huo, P. Kele, F. M. Andreopoulos, S. M. Pham and R. M. Leblanc, Org. Lett., 2001, 3, 3277-3280; L. Gao, J. Q. Wang, L. Huang, X. X. Fan, J. H. Zhu, Y. Wang and Z. G. Zou, Inorg. Chem., 2007, 46, 10287-10293; V. S. Jisha, A. J. Thomas and D. Ramaiah, J. Org. Chem., 2009, 74, 6667-6673; H. H. Wang, L. Xue, Z. J. Fang, G. P. Li and H. Jiang, New J. Chem., 2010, 34, 1239-1242.

11 T. Gunnlaugsson, J. P. Leonard and N. S. Murray, Org. Lett., 2004, 6, 1557-1560; R. Martinez, A. Espinosa, A. Tarraga and P. Molina, Org. Lett., 2005, 7, 5869-5872; Z. Xu, K. Baek, H. N. Kim, J. Cui, X. Qian, D. R. Spring, I. Shin and J. Yoon, J. Am. Chem. Soc., 2010, 132, 601-610.

12 L. Yang, R. McRae, M. M. Henary, R. Patel, B. Lai, S. Vogt and C. J. Fahrni, Proc. Natl. Acad. Sci. U. S. A., 2005, 102, 1117911184; E. W. Miller, L. Zeng, D. W. Domaille and C. J. Chang, Nat. Protoc., 2006, 1, 824-827; L. Zeng, E. W. Miller, A. Pralle, E. Y. Isacoff and C. J. Chang, J. Am. Chem. Soc., 2006, 128, 1011; Z. Xu, S. J. Han, C. Lee, J. Yoon and D. R. Spring, Chem. Commun., 2010, 46, 1679-1681; D. W. Domaille, L. Zeng and C. J. Chang, J. Am. Chem. Soc., 2010, 132, 1194-1195.

13 H. D. Axelrod, J. H. Cary, J. E. Bonelli and J. P. Lodge Jr, Anal. Chem., 1969, 41, 1856-1858; M. F. Choi and P. Hawkins, Anal. Chim. Acta, 1997, 344, 105-110; M. A. Spaziani, J. L. Davis, M. Tinani and M. K. Carroll, Analyst, 1997, 122, 1555-1557; J. Rodriguez-Fernandez, J. M. Costa, R. Pereiro and A. Sanz-Medel, Anal. Chim. Acta, 1999, 398, 23-31.

14 M. G. Choi, S. Cha, H. Lee, H. L. Jeon and S.-K. Chang, Chem. Commun., 2009, 7390-7392; X. F. Yang, L. Wang, H. Xu and M. Zhao, Anal. Chim. Acta, 2009, 631, 91-95; L. Zhang, X. Lou, Y. Yu, J. Qin and Z. Li, Macromolecules, 2011, 44, 5186-5193.

15 G. Patonay and M. D. Antoine, Anal. Chem., 1991, 63, 321A327A; R. B. Thompson, Top. Fluoresc. Spectrosc., 1994, 4, 151181; S. Stoyanov, Pract. Spectrosc., 2001, 25, 35-93; W. M. Leevy, S. T. Gammon, H. Jiang, J. R. Johnson, D. J. Maxwell, M. Marquez, D. Piwnica-Worms and B. D. Smith, J. Am. Chem. Soc., 2006, 128, 16476-16477; W. M. Leevy, S. T. Gammon, J. R. Johnson, A. J. Lampkins, H. Jiang, M. Marquez, D. Piwinica-Worms and B. D. Smith, Bioconjugate Chem., 2008, 19, 686-692.
16 J. Fabian, H. Nakazumi and M. Matsuoka, Chem. Rev., 1992, 92, 1197-1226; J. V. Frangioni, Curr. Opin. Chem. Biol., 2003, 7, 626-634; B. A. Smith, W. J. Akers, W. M. Leevy, A. J. Lampkins, S. Z. Xiao, W. Wolter, M. A. Suckow, S. Achilefu and B. D. Smith, J. Am. Chem. Soc., 2010, 132, 67-69; J. M. Baumes, J. J. Gassensmith, J. Giblin, J.-J. Lee, A. G. White, W. J. Culligan, W. M. Leevy, M. Kuno and B. D. Smith, Nat. Chem., 2010, 2, 1025-1030.

17 R. M. Duke, E. B. Veale, F. M. Pfeffer, P. E. Kruger and T. Gunnlaugsson, Chem. Soc. Rev., 2010, 39, 3936-3953.

18 S. Banerjee, E. B. Veale, C. M. Phelan, S. A. Murphy, G. M. Tocci, L. J. Gillespie, D. O. Frimannsson, J. M. Kelly and T. Gunnlaugsson, Chem. Soc. Rev., 2013, 42, 1601-1618.

19 X. Chen, T. Pradhan, F. Wang, J. S. Kim and J. Yoon, Chem. Rev., 2012, 112, 1910-1956.

20 N. Boens, V. Leen and W. Dehaen, Chem. Soc. Rev., 2012, 41, 1130-1172.

21 T. Kowada, H. Maeda and K. Kikuchi, Chem. Soc. Rev., 2015, 44, 4953-4972.

22 A. Mishra, R. K. Behera, P. K. Behera, B. K. Mishra and G. B. Behera, Chem. Rev., 2000, 100, 1973-2011.

23 D. Rehm and A. Weller, Isr. J. Chem., 1970, 8, 259; T. Egawa, K. Hanaoka, Y. Koide, S. Ujita, N. Takahashi, Y. Ikegaya, N. Matsuki, T. Terai, T. Ueno, T. Komatsu and T. Nagano, J. Am. Chem. Soc., 2011, 133, 14157.

24 C. Kar, M. D. Adhikari, A. Ramesh and G. Das, RSC Adv., 2012, 2, 9201-9206.

25 Y. Yang, Q. Zhao, W. Feng and F. Li, Chem. Rev., 2013, 113, 192-270.

26 K. P. Carter, A. M. Young and A. E. Palmer, Chem. Rev., 2014, 114, 4564-4601.

27 D. W. Boening, Chemosphere, 2000, 40, 1335-1340.

28 H. H. Harris, I. Pickering and G. N. George, Science, 2003, 301, 1203.

29 T. W. Clarkson, L. Magos and G. J. N. Myers, N. Engl. J. Med., 2003, 349, 1731-1737.

30 C. M. L. Carvalho, E.-H. Chew, S. I. Hashemy and J. Lu, J. Biol. Chem., 2008, 283, 11913-11923.

31 G. Guzzi and C. A. M. La Porta, Toxicology, 2008, 244, 1-12. 32 R. R. Lauwerys, A. M. Bernard, H. A. Reels and J.-P. Buchet, Clin. Chem., 1994, 40, 1391.

33 G. F. Nordberg, R. F. M. Herber and L. Alessio, Cadmium in the Human Environment, Oxford University Press, Oxford, UK, 1992.

34 Agency for Toxic Substances and Disease Registry, 4770 Buford Hwy NE, Atlanta, GA 30341, http://www.atsdr.cdc.gov/ cercla/07list.html.

35 E. L. Que, D. W. Domaille and C. J. Chang, Chem. Rev., 2008, 108, 1517-1549; C. J. Frederickson, J. Y. Koh and A. I. Bush, Nat. Rev. Neurosci., 2005, 6, 449-462; A. G. Scrimgeoura, C. H. Stahl, J. P. McClung, L. J. Marchitelli and A. J. Young, J. Nutr. Biochem., 2007, 18, 813-819; J. M. Berg and Y. Shi, Science, 1996, 271, 1081-1085.

36 B. L. Vallee and K. H. Falchuk, Physiol. Rev., 1993, 73, 79-118. 37 M. Hambidge, J. Nutr., 2000, 130, 1344S-1349S.

38 L. A. Lichten and R. Cousins, Annu. Rev. Nutr., 2009, 29, 153176. 
39 H. A. Benesi and J. H. Hildebrand, J. Am. Chem. Soc., 1949, 71, 2703-2707.

40 A. D. Becke, J. Chem. Phys., 1993, 98, 5648-5652; C. Lee, W. Yang and R. G. Parr, Phys. Rev. B: Condens. Matter Mater. Phys., 1988, 37, 785-789; D. Andrae, U. Haeussermann, M. Dolg, H. Stoll and H. Preuss, Theor. Chim. Acta, 1990, 77, 123-141.

41 M. J. Frisch, et al., Gaussian 09, Revision D.01, Gaussian, Inc., Wallingford CT, 2013.

42 L. He, W. Lin, Q. Xu, M. Ren, H. Wei and J.-Y. Wang, Chem. Sci., 2015, 6, 4530-4536.

43 J. Huang, Y. Xu and X. Qian, J. Org. Chem., 2009, 74, 21672170; H. Yang, Z. Zhou, K. Huang, M. Yu, F. Li, T. Yi and C. Huang, Org. Lett., 2007, 9, 4729-4732; J. F. Zhang, Y. Zhou, J. Yoon, Y. Kim, S. J. Kim and J. S. Kim, Org. Lett., 2010, 12, 3852-3855; M. Vendrell, D. Zhai, J. C. Er and Y. T. Chang, Chem. Rev., 2012, 112, 4391-4420; C. Kar, M. Adhikari, A. Ramesh and G. Das, Inorg. Chem., 2013, 52, 743.
44 Y.-K. Yang, K.-J. Yook and J. Tae, J. Am. Chem. Soc., 2005, 127, 16760-16761.

45 K. Li, Y. Xiang, X. Wang, J. Li, R. Hu, A. Tong and B. Z. Tang, J. Am. Chem. Soc., 2014, 136, 1643-1649; F.-J. Huo, C.-X. Yin, Y.-T. Yang, J. Su, J.-B. Chao and D.-S. Liu, Anal. Chem., 2012, 84, 2219-2223; S. Chaudhuri, S. Kundu, M. K. Biswas, T. Weyhermuller and P. Ghosh, Inorg. Chim. Acta, 2015, 430, 199-207.

46 R. Krämer, Angew. Chem., 1998, 110, 804-806; Angew. Chem., Int. Ed., 1998, 37, 772-773; J. Yoon, N. E. Ohler, D. H. Vance, W. D. Aumiller and A. W. Czarnik, Tetrahedron Lett., 1997, 38, 3845-3848; A. Torrado, G. K. Walkup and B. Imperiali, J. Am. Chem. Soc., 1998, 120, 609-610; M. A. Bernardo, F. Pina, B. Escuder, E. Garcia-España, M. L. Godino-Salido, J. LaTorre, S. V. Luis, J. A. Ramirez and C. Soriano, J. Chem. Soc., Dalton Trans., 1999, 915-921.

47 K. P. Carter, A. M. Young and A. E. Palmer, Chem. Rev., 2014, 114, 4564-4601. 